Journal of Southeast Asian

\title{
From Creative Writing To a Self's Liberation: A Monologue of a Struggling Writer
}

Ethan Trinh

Georgia State University, ethan.trinh14@gmail.com

Follow this and additional works at: https://docs.lib.purdue.edu/jsaaea

Part of the Adult and Continuing Education and Teaching Commons, Bilingual, Multilingual, and Multicultural Education Commons, Curriculum and Instruction Commons, Curriculum and Social Inquiry Commons, Higher Education and Teaching Commons, Language and Literacy Education Commons, and the Poetry Commons

\section{Recommended Citation}

Trinh, Ethan (2019) "From Creative Writing To a Self's Liberation: A Monologue of a Struggling Writer," Journal of Southeast Asian American Education and Advancement. Vol. 14 : Iss. 1, Article 9.

DOI: $10.7771 / 2153-8999.1184$

Available at: https://docs.lib.purdue.edu/jsaaea/vol14/iss1/9

This document has been made available through Purdue e-Pubs, a service of the Purdue University Libraries. Please contact epubs@purdue.edu for additional information.

This is an Open Access journal. This means that it uses a funding model that does not charge readers or their institutions for access. Readers may freely read, download, copy, distribute, print, search, or link to the full texts of articles. This journal is covered under the CC BY-NC-ND license. 


\title{
Education and Advancement
}

Vol. 14 Iss. 1 (2019)

\author{
WWW.JSAAEA.org
}

\author{
Creative and Literary Works
}

\section{From Creative Writing To a Self's Liberation: A Monologue of a Struggling Writer}

\author{
Ethan Trinh \\ Georgia State University
}

\begin{abstract}
The pressure of being alone in a new country and of surviving in a competitive academia has scared me to death. I cannot find any better way to heal me other than writing. Writing helps me make sense of the worlds and come closer to my true self. This piece is journeying from my own struggles of a Vietnamese, queer, immigrant teacher to accept who I am as a writer. In addition, writing this piece helps me get closer to decademizing academic writing in higher education.
\end{abstract}

Keywords: Writing, identity, liberation, struggling, academia, writer of color, monologue, school

\footnotetext{
(C)

SDRERIIEHISRESEREDDReaders are free to copy, display, and distribute this article, as long as the work is attributed to the author(s) and the Journal of Southeast Asian American Education \& Advancement, it is distributed for non-commercial purposes only, and no alteration or transformation is made in the work. More details of this Creative Commons license are available at http://creativecommons.org/licenses/by-nc-nd/3.0/. All other uses must be approved by the author(s) or JSAAEA. Journal of Southeast Asian American Education \& Advancement, Vol. 14. Iss. 1. (2019) ISSN: 2153-8999
} 
"The act of writing is the act of making soul, alchemy."

Gloria Anzaldúa (2012)

I am listening to one of my favorite blue songs, getting a cheap wine from a local store, reading an Anzaldúa's book, and thinking about myself on a Friday night. What have I been doing since I first came to the doctoral program? I remembered at the beginning of the semester; I felt alone, exhausted, and friendless. I was struggling with a framework or formula that the academia wants me to write. I refused to do so; that is not who I am as a writer. The pressure of being alone in a new country and of surviving in a competitive academia has scared me to death. My fingers are not strong enough to type in.

While reading Anzaldúa, I am thinking about my old self. I was attempting to strip away all labels that the society tags on me: a Vietnamese, queer, accented ESL (English as a Second Language) teacher; a person who is learning how to unlearn hegemonic masculinity; a doctoral student whose responsibilities are meant to get publications; a son who is taking burdens on his shoulder to help his family to overcome financial issues; a son who is learning how to heal scars from family violence abuse (Trinh, 2018); a writer who is struggling with translanguaging and codeswitching in his writing in academia. I felt pressure in the air and got lost in the dark.

"Why did I have to strip away from those labels?" Selfishness, you may think. I was alone in a liminal space where I had to figure things out by myself. I usually ask myself: "How can I shift my perspectives from a submissive, well-trained technician to be an independent and critical scholar?", "How can I listen to another me?", "Is he screaming in silence?", "Is he struggling in silence?", "Is he afraid to tell what he thinks in mind?", "Is he escaping with a fear of being found and seen for who he is?", "What are you thinking?", I was wondering. I am trying to understand 
my queer self. What am $\mathrm{i}$, with lowercase for the ego "I"? What am $\mathrm{i}$ in a lonely world—in a midst of noises and voices? Who am i to critique the world based off of the eye of a neophyte? I cannot find any better way to heal other than writing so that writing can help me make sense of the world and come closer to my true self.

Thru writing, I create my new fate. I am escaping from the cage where asks people to follow thru. Yes, "thru" instead of "through" in academic writing. I am tired of following thru with what society requires me to do. I'm tired of being assimilated while I can be me. I'm tired of rules, conventions, and doctrines. I am tired of running and chasing the unknown and un-me. As my friend says, "You have to play with its own rules." I know rules, but I refuse to play with them. The reality is harsh, dark, and dry. It is not like the cheap wine that I am tasting now, which is sweet, smooth and more importantly, I chose it. I chose this bottle of wine to spend a night. I chose it because I am the creator of this life - my own life. I don't belong to anyone but myself. I feel an urge to respond to that self-ness (you can call "selfishness" if you want to; that's fine to me) - thru writing. My loneliness will be relieved when I write. My mind is set free when I write. My soul is uncuffed from the cage, from the formula, from liminal spaces. I write to be me. I write to see thru me, whether or not the society accepts me. I liberate myself thru writing, where I cannot find any concrete space to get loose of it.

While seeing a way out, I am reflecting on so-called "pedagogical approach" in instructing writing in schools. As an ESL teacher, how can I encourage my students to write creatively and take pride in their home language and identit(ies)? How can I instruct them to write toward breaking the limit of "standardized English writing?" Reflecting on my struggles in finding my gender, racial, ethnic identities, I am thinking about my students and their silences in school as 
they encountered Xenophobia, Islamophobia (Trinh, 2018) and homophobia (Trinh, 2019). I, therefore, question about the role of school. "What is school?", I wondered.

\section{SCHOOL}

School should teach students to be racist, to be homophobic, to be xenophobic, you name a few. School should be segregated based on socio-economic statuses, classes, skin colors, races, gender, and sexual preferences, you name a few.

School is a wrong place for mercy, empathy and understanding

Toward marginalization

School should practice zero-tolerance policies when rules are broken.

School is a place where no soft heart exists.

School is a living hell.

How dare you to say so!

How dare you to think that way!

How dare you,

Son of $a b^{*} t c h$ !

I am writing in anger,

I cannot put a full stop for this;

in frustration, in utmost pain

Because somewhere in a space of a classroom.

the pain is still............... goin'

A student is undergoing that experience

A student is undergoing that stereotype

A student is silenced,

is not brave enough to raise their hands

is not strong enough to tell testimonies

is not acknowledged for who they are

is

is

cryin' inv s ble

Who am I? - Tôi là ai?

as a teacher, an educator,

a Vietnamese queer nepantla,

who lives across the borders and cultures, who lives between and among worlds,

who sees and contrasts the differences

TO break down hegemony,

TO deconstruct colonialism,

TO tear away hatred, disparity, racism

I teach to connect, to link, to heal, to share with my students

$$
\text { In - the - living - hell }
$$


TO make $a$ dream of change, of transformation, of revolution happen

WITH our pens, our strong wills, our voices, our breaths, our commitments to change We have the dream

TO CHANGE

a living hell

TOGETHER

I can choose a formal way to describe and argue what school is, but I opted out. I decided to write creatively from the beginning in order to decademize academic writing in higher education. I write toward compassion. I write toward social justice and equity. I write toward embracing my students whose voices are silenced due to their languages and fear of being judged. I write toward embracing others, especially scholars of color so that we could create a space to write, to contribute our voices, and to find belonging and identities in academia. Therefore, this piece is wholeheartedly meaningful to me because I firmly believe each of us has important and beautiful stories to share; and we can share it creatively. During courses in a doctoral program, I ethanize my writing. To me, ethanizational writing is a HAPPY (Healing, $\underline{\text { A wakening, }}$ $\underline{\text { Painfulness, }}$ Progressiveness, and $\underline{\mathbf{Y}}$ olo) process that a writer has a chance to sit down to converse with a self, to heal the scars (both mentally and physically), to unpuzzle mysteries, to connect dots, to retrieve memories, to forgive, to critique and to give birth to oneself one more time. You can be whoever-zational you want to be thru writing, and that should be a HAPPY process.

As putting my heart in the poem and this monologue, I want to be a part of this historic movement so that I can be with students, scholars, and writers of color. I believe in the power of connection and wisdom sharing that can contribute to the work of liberation and social justice. I believe our voices matter. I believe we matter, and so are our writings. That is why I write. 


\section{References}

Anzaldua, G. (2012). Borderlands/La frontera: The new mestiza ( $4^{\text {th }}$ ed.). San Francisco, CA: Aunt Lute Books.

Trinh, E. (2019). Breaking down the coatlicue state to see a self: Queer voices within a circle. The Assembly. Retrieved from https://www.colorado.edu/journal/assembly/2019/06/05/breaking-down-coatlicue-statesee-self-queer-voices-within-circle

Trinh, E. (2018). How hugging mom teaches me the meaning of love and perhaps beyond. The Journal of Faith, Education and Community, 2(1), 1-14.

Trinh, E. (2018, August 21). Educating students is more than teaching Content. [Video file]. Retrieved from https://www.youtube.com/watch?v=WQ1X5n4EzLY\&t=34s 


\section{About the Author}

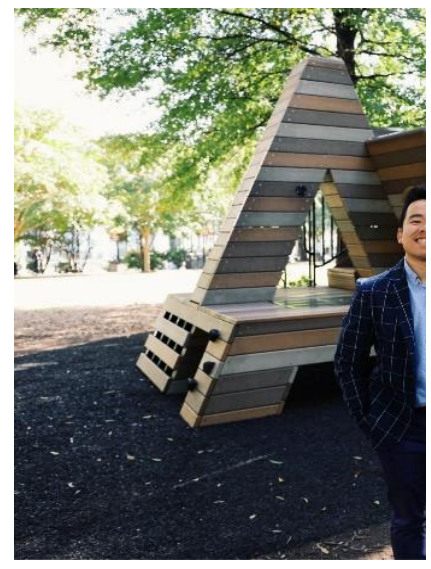

My picture will be blurry and un-united until we are getting together to work toward social justice for all.

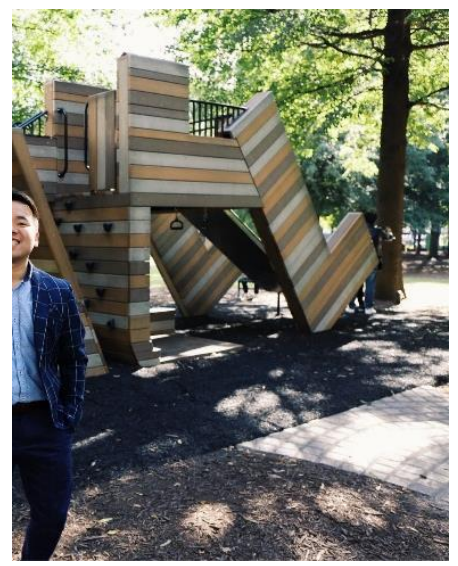

Ethan Trinh is a transnational, queer, Vietnamese ESL Instructor in Atlanta, Georgia, USA. Currently, Ethan is a doctoral student at Department of Middle and Secondary Education, Georgia State University, and is serving as a 2019 TESOLers Social Responsibilities Interest Section (SRIS) Newsletter Co-Editor. He is inspired to do research about queer transnationals, ESL, Vietnamese Studies, and Chicana Feminism. 


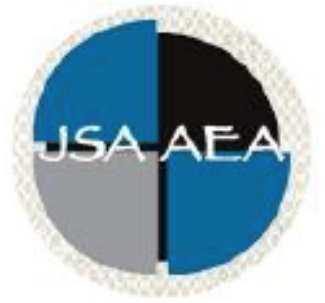

Vol.14 Iss.1 (2019)

\title{
Journal of Southeast Asian American Education and Advancement
}

\author{
www.JSAAEA.org
}

\section{Editor}

Dr. Wayne E. Wright

Purdue University

Associate Editors

Dr. Chhany Sak-Humphry

University of Hawaii at Manoa

Dr. Phitsamay Sychitkokhong Uy

University of Massachusetts, Lowell

\author{
Book Review Editor \\ Dr. Vichet Chhuon \\ University of Minnesota \\ Creative Works Editor \\ Bryan Thao Worra \\ Lao Assistance Center \\ Journal Manager \\ Fang Gao \\ Purdue University
}

\section{Editorial Review Board}

Dr. Steve Arounsack

California State University, Stanislaus

Dr. Sovicheth Boun

Salem State University

Dr. Virak Chan

Purdue University
Dr. Carl L. Bankston III

Tulane University

Dr. Phala Chea

Lowell Public Schools

Dr. George Chigas

University of Massachusetts, Lowell 


\author{
Dr. Loan Dao \\ University of Massachusetts Boston \\ Dr. Changming Duan \\ University of Missouri-Kansas City \\ Dr. Sothy Eng \\ Lehigh University \\ Dr. Vincent K. Her \\ University of Wisconsin, Eau Claire \\ Dr. Peter Nien-Chu Kiang \\ University of Massachusetts, Boston \\ Dr. Kevin K. Kumashiro \\ University of Illinois, Chicago \\ Dr. Ha Lam \\ Eastern Mennonite University \\ Dr. Jonathan H. X. Lee \\ San Francisco State University \\ Dr. Monirith Ly \\ Royal University of Phnom Penh \\ Dr. Bic Ngo \\ University of Minnesota \\ Dr. Leakhena Nou \\ California State University, Long Beach \\ Dr. Mark Pfeifer \\ SUNY Institute of Technology \\ Dr. Loan T. Phan \\ University of New Hampshire \\ Dr. Karen Quintiliani \\ California State University, Long Beach \\ Dr. Angela Reyes \\ Hunter College \\ The City University of New York \\ Dr. Fay Shin \\ California State University, Long Beach \\ Dr. Christine Su \\ College of San Mateo \\ Dr. Alisia Tran \\ Arizona State University \\ Dr. Khatharya Um \\ University of California, Berkeley \\ Dr. Kim Tran \\ University of California, Los Angeles, \\ Glendale Community College \\ Dr. Soua Xiong \\ California State University, Fresno \\ Dr. Zha Blong Xiong \\ University of Minnesota
}

Dr. Hien Duc Do

San Jose State University

Dr. Sophal Ear

Occidental College

Dr. Jeremy Hein

University of Wisconsin, Eau Claire

Dr. Nancy H. Hornberger

University of Pennsylvania

Dr. Peter Tan Keo

New York University

Dr. Yvonne Kwan

San Jose State University

Dr. Ravy Lao

California State University, Los Angeles

Dr. Stacey Lee

University of Wisconsin, Madison

Dr. Sue Needham

California State University, Dominguez Hills

Dr. Max Niedzwiecki

Daylight Consulting Group

Dr. Clara Park

California State University, Northridge

Dr. Giang Pham

University of Massachusetts Amherst

Dr. Malaphone Phommasa

University of Clifornia Santa Barbara

Dr. Kalyani Rai

University of Wisconsin-Milwaukee

Dr. Cathy J. Schlund-Vials

University of Connecticut, Storrs

Dr. Nancy J. Smith-Hefner

Boston University

Dr. Yer J. Thao

Portland State University

Dr. Monica M. Trieu

Purdue University

Dr. Silvy Un

Saint Paul Public Schools

Dr. Linda Trinh Vo

University of California, Irvine

Dr. Molly Wiebie

The University of Texas at Austin

Dr. Yang Sao Xiong

The University of Wisconsin-Madison 


\section{Doctoral Student Editorial Review Board}

\author{
Diana Chandara \\ University of Minnesota \\ Bao Diep \\ University of Minnesota \\ Nielsen Hul \\ Cornell University \\ Vanessa Na \\ University of California, San Diego \\ Hoa Nha Nguyen \\ Boston College \\ Linda Marie Pheng \\ University of Wisconsin-Madison \\ Mai Vang \\ University of Massachusetts Boston \\ Thong Vang \\ University of Minnesota
}

\author{
Linh Dang \\ University of Rochester
}

Annie BichLoan Duong

San Joaquin County Office of Education

Dung Minh Mao

University of Minnesota

Thien-Huong Ninh

University of Southern California

Khoi Nguyen

George Mason University

Krissyvan Truong

Claremont Graduate University

Melissa Vang

San Diego State University 